\title{
New sauropodomorph and cynodont remains from the Late Triassic Sacisaurus site in southern Brazil and its stratigraphic position in the Norian Caturrita Formation
}

Júlio C.A. Marsola, Jonathas S. Bittencourt, Átila A.S. Da Rosa, Agustín G. Martinelli, Ana Maria Ribeiro, Jorge Ferigolo, and Max C. Langer

Acta Palaeontologica Polonica 63 (4), 2018: 653-669 doi:https://doi.org/10.4202/app.00492.2018

Sacisaurus agudoensis is the only silesaurid known from the Triassic beds of the Santa Maria

Supersequence and the correlation of its type locality to the other Triassic deposits of south Brazil has always been controversial. In an attempt to improve this, a handful of dinosaur and cynodont remains found associated to $S$. agudoensis are here described and compared. The anatomy of the sauropodomorph is more similar to that of Norian forms such as Pantydraco caducus and Unaysaurus tolentinoi than to that of Carnian taxa such as Saturnalia tupiniquim and Pampadromaeus barberenai . The cynodonts recovered based on isolated teeth include a brasilodontid and a Riograndia-like form. This assemblage is consistent with a Norian age, as is also suggested by local stratigraphic correlation, which positions the site in the Caturrita Formation.

Key words: Dinosauria, Sauropodomorpha, Dinosauriformes, Cynodontia, Triassic, Norian, Caturrita Formation, Brazil.

Júlio C.A. Marsola [juliomarsola@gmail.com] and Max C. Langer [1anger.mc@gmail.com ], Departamento de Biologia, FFCLRP, Universidade de São Paulo, Ribeirão Preto, SP, 14040-901, Brazil. Jonathas S. Bittencourt [sigmaorionis@yahoo.com.br

], Departamento de Geologia, Universidade Federal de Minas Gerais, Belo Horizonte, MG, 31270-901, Brazil. Átila A.S. Da Rosa [atila@smail.ufsm.br ], Laboratório de Estratigrafia e Paleobiologia, Departamento de Geociências, Universidade Federal de Santa Maria, Santa Maria, RS, 97.105-900, Brazil. Agustín G. Martinelli [agustin martinelli@yahoo.com.ar], Laboratório de Paleontologia de Vertebrados, Departamento de Paleontologia e Estratigrafia, Instituto de Geociências, Universidade Federal do Rio Grande do Sul, Porto Alegre, RS, 91540-000, Brazil. Ana Maria Ribeiro [ana.ribeiro@fzb.rs.gov.br ] and Jorge Ferigolo [jorgeferigolo@gmail.com], Seção de Paleontologia, Museu de Ciências Naturais, Fundação Zoobotânica do Rio Grande do Sul, Porto Alegre, RS, 90690-000, Brazil. 
This is an open-access article distributed under the terms of the Creative Commons Attribution License (for details please see creativecommons.org), which permits unrestricted use, distribution, and reproduction in any medium, provided the original author and source are credited.

\footnotetext{
FoF Full text $(889.6 \mathrm{kB})$ ।

FoF Supplementary file $(76.0 \mathrm{kB})$
} 